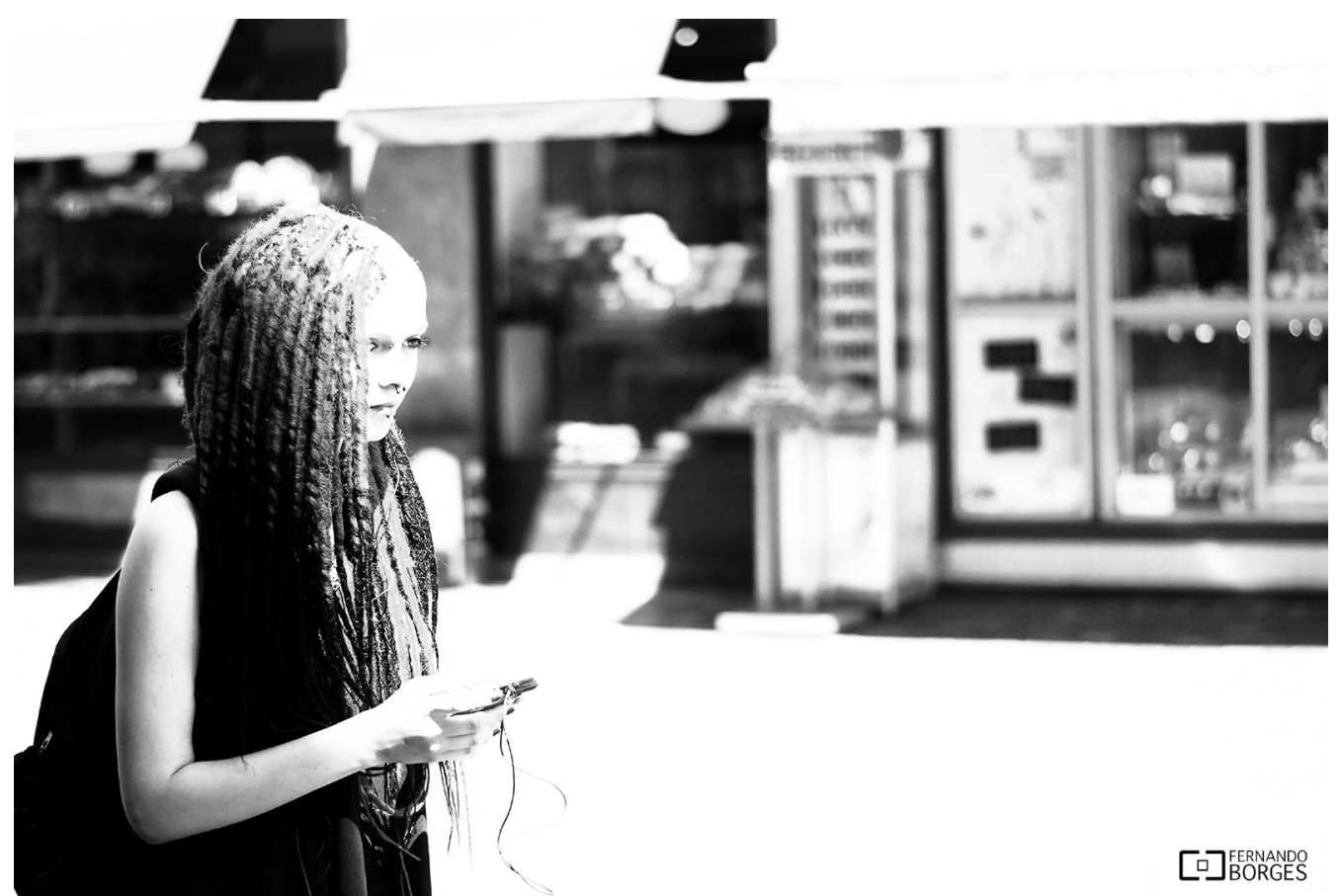

Connection Copenhagen, 20/07/2013. Foto gentilmente cedida por Fernando Borges. Facebook: Fernando Borges Photography https://www.facebook.com/pages/FernandoBorgesPhotography/211302065696898? ref = hl. 


\title{
Janelas urbanas e imagens eletrônicas: 0 mal olhado da modernidade
}

\author{
Eliana Monteiro ${ }^{1}$
}

\begin{abstract}
Resumo:
Este texto discute o material videográfico de 33 horas produzido pela aposentada conhecida como Dona Vitória, que durante dois anos filmou o tráfico de drogas da janela de sua casa em Copacabana, realizando ao todo 22 fitas, entregues à polícia em 2005. Reflexões da relação entre áudio e imagem e a multiplicidade de vozes (polifonia) das histórias desvendadas por Dona Vitória que trazem um novo estatuto de visibilidade que rompe com a hegemonia do diálogo produzido pela mídia.
\end{abstract}

Palavras chave: Tecnologias. Imagem. Vídeo. TV.

\section{ABSTRACT:}

This paper discusses the 33-hour videographic material produced by the pensioner knows as Dona Vitória, Who for two yers filmed the drug traffic from the window of her house in Copacabana, making a total of tapes, handed over to the Police in 2005. Reflections on the relationship between áudio and image and the multiplicity of voices (polyphony) in Dona Vitória's story that unveils a new statute of a Picture that breaks with the hegemonic media dialogue.

Keywords: Technologies. Picture. Video. TV.

\footnotetext{
1 Doutora em Comunicação e Cultura, na linha de pesquisa: Tecnologias da Comunicação e Estéticas, pela ECO (Escola de Comunicação da UFRJ). Curso de extensão: "Théories dês formes visuelles: Cinéma et art contemporain, les vitesses de l'image" (Université Sorbonne Nouvelle - Paris 3). Jornalista. Professora da FACHA - Faculdades Integradas Hélio Alonso. E-mail: elianamonteiro.55@gmail.com 
A multiplicação dos dispositivos eletrônicos visuais disponíveis no mercado aliado ao apelo publicitário tornou-se um campo fértil para o surgimento de uma sociedade sustentada numa grande rede de visibilidade. Essa rede se expande desde as câmeras de vigilância nos espaços públicos, aparelhos celulares, webcams, máquinas e filmadoras digitais, até os satélites de observação capazes de captar imagens do planeta. As câmeras de vigilância se multiplicam por estradas, aeroportos, ruas, supermercados, bancos, fábricas, escolas, como diz Arlindo Machado: "Essas câmeras estão colocadas nos lugares mais estratégicos, ocupando os ângulos mais privilegiados de visão e distribuídas no espaço de modo a não deixar um único ponto livre do voyeurismo automático" (Machado, 1993,p.220)

Essa multiplicação de dispositivos de vigilância já nos permite observar uma transição de uma estética clássica da vigilância para o que ocorre hoje. Quem nos chama a atenção para essa mudança é Consuelo Lins e Fernanda Bruno:

Podemos talvez vislumbrar nesses dois "filmes de amor" ["Una tarde de amor" e "Uma"] indícios de transição de uma estética "clássica da vigilância, ligada às sociedades disciplinares, que distinguia o vigia do vigiado, para uma prática contemporânea do controle espraiada pelo campo social, onde a questão não é mais, ou apenas, "quem vigia o vigia?". mas "como diferenciar vigias e vigiados?" A emergência desse "estágio clássico" se dá, no campo das artes plásticas, já no final dos anos 60 com as instalações de Michael Snow e Bruce Nauman; os traços estéticos e políticos mais marcantes dos trabalhos das décadas de 70 e 80 são, por um lado, a reorganização e modificação dos parâmetro dos dispositivos de vigilância e, por outro, a retomada e subversão das suas características plásticas (fixidez da câmera, automatismo da gravação, imagem de baixa qualidade em preto e branco).(Bruno e Lins, 2007, p.38-9)

Estar-se-ia diante da universalização do panóptico? Foucault, ao falar do panóptico a partir dos escritos de Julius, diz que "nele se via bem mais que um talento arquitetural: um acontecimento na história do espírito humano. Aparentemente, não passa da solução de um problema técnico; mas através dele, se constrói um tipo de sociedade" (Foucault, 1997, p.190): a sociedade disciplinar.

É interessante como Foucault desenvolve seu raciocínio, diz ele que a Antiguidade foi uma civilização do espetáculo: "tornar acessível a uma multidão de homens a inspeção de um pequeno número de objetos". Para solucionar esse problema, surge uma arquitetura dos templos, teatros, circos. No caso da sociedade moderna (disciplinar) existe um problema contrário: "proporcionar a um pequeno número, ou mesmo a um só, a visão instantânea de uma grande multidão." Possibilidade de investir sobre os corpos moldando-os:

Julius via como um processo histórico cabalmente realizado o que Bentham descrevera como um programa técnico. Nossa sociedade não é de espetáculos, mas de vigilância; sob a superfície das imagens, investem-se os corpos em profundidade; atrás da grande abstração da troca, se processa o treinamento minucioso e concreto das forças úteis; os circuitos da comunicação são os suportes de uma acumulação e centralização do saber; o jogo dos sinais define os pontos de apoio do poder; a totalidade do indivíduo não é amputada, reprimida, alterada por nossa ordem social, mas o indivíduo é cuidadosamente fabricado, segundo uma tática das forças e dos corpos (Foucault,1997, p190).

Ora, hoje se está em um momento de transição: deixa-se de ser uma sociedade disciplinar e está-se tornando uma sociedade de controle. A sociedade atual introduziu modificações no modelo panóptico, característico da sociedade disciplinar. De algum modo 
volta-se à sociedade do espetáculo, no sentido de que muitos observam poucos (sinoptismo). Atualmente o que se evidencia é a alternância dos lugares de vigiados/vigilantes condição que vai depender de qual lado da lente eles se encontram.

\section{Dona Vitória e o olhar da vigilância}

Recentemente, em agosto de 2005, uma senhora aposentada de 80 anos, com o nome fictício de Dona Vitória, se tornou conhecida na mídia através de uma reportagem publicada no jornal Extra ${ }^{2}$ na qual ela denuncia 26 pessoas envolvidas no tráfico de drogas, entre elas nove são policiais militares. Dona Vitória, da janela de seu apartamento no bairro de Copacabana e de posse de uma minicâmera VHS na mão, passa a gravar, às escondidas, o movimento do tráfico na Ladeira dos Tabajaras. Nas imagens aparecem traficantes armados negociando drogas, não só entre eles, mas com consumidores menores de idade.

2 A reportagem foi publicada no jornal "Extra" em 20 de fevereiro de 2006. Em 17 de abril de 2006, no mesmo jornal é publicada a reportagem que trata da condenação dos 26 envolvidos nos crimes.

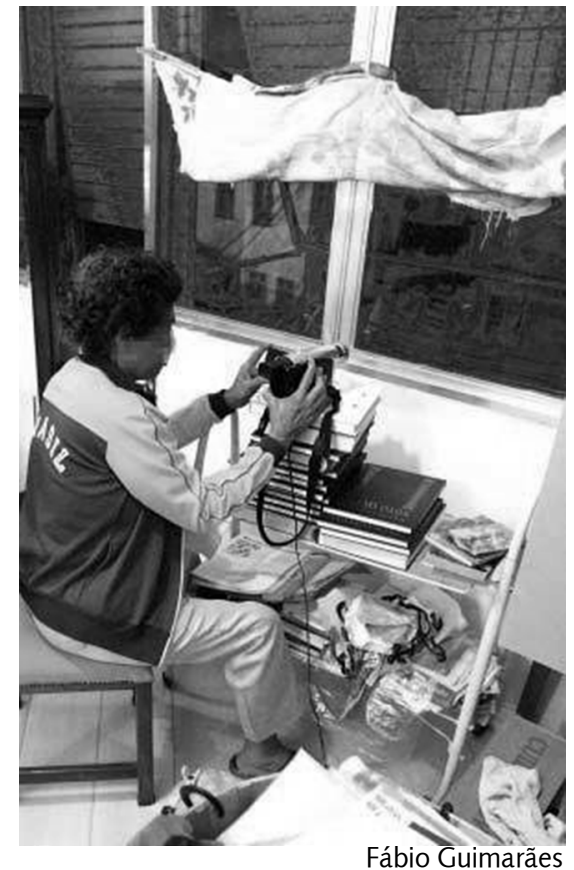

Extra - 24 de agosto de 2005 - Primeira página

De início, ao se verem as imagens - as primeiras foram gravadas em dezembro de 2003 -, nota-se que estão tremidas, percebese entre Dona Vitória e a máquina uma falta de intimidade. O problema da tremedeira é logo solucionado quando Dona Vitória improvisa um "tripé" com uma mesinha de televisão, livros e listas telefônicas. A cadeira, com algumas almofadas, já fica preparada estrategicamente em frente à janela (Gusmão, 2006, p.50).

O que chama a atenção é a facilidade com que Dona Vitória passa a manusear a câmera (são cerca de trinta e três horas de gravação), disparando o zoom, realizando panorâmicas e construindo planos que denunciam através dessa "montagem visual" uma estética que se aproxima, num primeiro momento da estética da vigilância. Muito embora as imagens capturadas pela aposentada se aproximem, à primeira vista, da narrativa de vigilância, há 
entre elas diferenças e identidades.

Em primeiro lugar, as imagens capturadas pelas câmeras de vigilância não implicam na presença de nenhum olho de um sujeito por trás das lentes, elas próprias regem o processo de vigilância, onde predomina "uma visão sem olhar em que a câmera de vídeo está submetida a um computador (...)" (Virilio, 1996, p.86). Enquanto as imagens capturadas pela câmera da aposentada têm por trás de sua lente o olho do sujeito que possibilita estabelecer uma outra ordem narrativa, é uma visão na qual o olhar organiza o relato.

Por outro lado, a câmera oculta usada por Dona Vitória se associa ao dispositivo político da denúncia (a câmera escondida) passando a reproduzir, de certo modo, o modelo controlador exercido pelos órgãos oficiais através dos dispositivos de vigilância. Tanto isto é verdadeiro que as imagens, ao chegarem ao conhecimento desses órgãos, levaram a Polícia Militar a identificar e prender os indivíduos envolvidos nas ações do tráfico de drogas na Ladeira dos Tabajaras, tal quais as imagens capturadas pelos dispositivos de vigilância oficiais são capazes de fazer.

Em terceiro lugar é preciso observar que da mesma maneira que estas imagens se aproximam no modo de sua captação, isso é, tanto uma como a outra constroem uma narrativa de vigilância, elas se diferenciam por suas características temporais. Para explicitar isso, comparemos as imagens de Dona Vitoria com aquelas capturadas pela CET-Rio.

As imagens da CET-RIO aparecem nos telejornais ao vivo, em um tempo simultâneo aos acontecimentos. São imagens produzidas no próprio tempo de duração do acontecimento, isto é, são imagens em que a referência de tempo do acontecimento (lentidão no trânsito, interrupção do tráfego) acontecem sem rupturas, reproduzem o instante de sua captura.

As imagens das câmeras de vigilância quando exibidas na televisão, embora em videoteipe, trazem consigo característica do "ao vivo", já que seu tempo de duração é o mesmo do acontecimento. Tem-se uma narrativa do agora onde a cena acontece por inteiro e como tal é exibida nas telas da televisão, isto é, no tempo simultâneo entre as personagens envolvidas na ação e o espectador.

No caso da gravação de dona Vitória, embora seja em videoteipe, ela traz consigo uma força narrativa, associada ao momento que ela está vivendo. Cada vez que o vídeo é exibido, atualiza um presente vivido pela aposentada. Isso sucede porque durante quase toda a filmagem ouve-se a voz off de Dona Vitória, mas ocorre que na maior parte das vezes, o que é narrado não coincide com o que é visível na tela. Isso quer dizer que Dona Vitória não "fala" daquilo que seus olhos estão vendo, mas do que é invisível a eles.

Nesses termos, a questão tratada por dona Vitória no vídeo não se coloca unicamente naquilo que transparece nas imagens (o tráfico de drogas na Ladeira dos Tabajaras), mas naquilo que não se vê nelas. Esse dualismo provocado entre áudio e vídeo, entre o dentro e o fora da narrativa expressa de modo tocante, a angústia que experimenta a aposentada diante dos acontecimentos. É a partir desta configuração superposta entre o visível e o invisível que se parte para localizar o caráter destas imagens.

\section{A voz do invisível}

A percepção visual de Dona Vitória, ao filmar as ações do tráfico na Ladeira dos Tabajaras, se inscreve no próprio mundo em que ela habita, "o mundo natural e o mundo 
histórico com todos os vestígios humanos que é feito"; as particularidades desse mundo da aposentada são refletidas na sua voz off.

Essa minha causa na Justiça vai parar nos direitos humanos internacionais, porque eu não posso ficar assim nessa situação, com 80 anos de vida. Todos os vizinhos têm suas famílias, vão embora, fogem, saem daqui, têm outros lugares para morar. Eu não tenho. Eu vou pedir ajuda e Deus vai estar na minha companhia, junto de mim para quando alguém ouvir essa fita ter um pouco de pena, um pouco de consciência do que está acontecendo aqui. Não dá mais para viver nesse lugar. A Justiça não está dando atenção ao que acontece. Eu estou há um ano, desde março, pedindo ajuda. Há um ano eu estou na Justiça, pedindo socorro"3

Dona Vitória constrói pela voz off uma narrativa subjetiva, pessoal, autônoma e que, portanto, independe das imagens. Essa ruptura na relação entre o que é visto e o que é dito dá ao material fílmico uma dimensão que foge ao modelo clássico de construção do off. Nesses termos a voz off da aposentada passa a ser uma fala que envolve sensações constituídas na sua própria experiência, onde a narrativa transcende aquilo que está determinado na imagem.

Assim, a voz off de Dona Vitória surge como um desabafo, um monólogo interior ${ }^{4}$. Este se diferencia do monólogo tradicional não só na sua matéria quanto na sua forma:

(...) quanto à sua matéria, é uma expressão

\footnotetext{
3 Jornal Extra. Depoimentos de Dona Vitória em 31 de julho de 2006. As imagens que são citadas estão nos seis minutos de vídeo que fazem parte do arquivo do Departamento de Jornalismo da TVE no Rio de Janeiro. 4 A expressão" monólogo interior" se constitui em uma técnica literária criada pelo escritor francês (de pouca expressão nas letras) Édouard Dujardin (1861- 1949) - a técnica aparece pela primeira vez no romance Les Lauriers sont coupés - publicado em 1887 - nela o autor diferencia o monólogo interior do monólogo tradicional, não só na sua matéria como na sua forma. SILVA, Vitor Manoel Aguiar e. Teoria da Literatura. São Paulo: Almedina, 2004 p. 62
}

do pensamento mais íntimo, mais próximo do inconsciente; quanto ao seu espírito, é um discurso anterior a qualquer organização lógica, reproduzindo esse pensamento no seu estado nascente e com aspecto de recém-vindo; quanto à sua forma, realiza-se em frases diretas reduzidas ao mínimo de sintaxe (Dujardinb apud Silva, 2004, p. 297).

Esse mesmo procedimento encontra-se na fala de Dona Vitória: “Outro dia quando eu fui trabalhar, contei os passos daqui até o $19^{\circ}$ Batalhão. Não chega a 400 passos. $O$ traficante está gritando, e eu garanto que eles estão ouvindo de lá" (Gusmão, 2006, p.82).

Voltando à frase anterior, a aposentada diz: “(...) quando alguém ouvir esta fita vai ter um pouco de pena (...)" . Cabe grifar nesta fala a palavra ouvir; ela não diz: "quando alguém ver esta fita", o que seria o mais comum já que o acontecimento da Ladeira dos Tabajaras está, naquele momento, sendo filmado por ela própria. Há incontestavelmente nesse instante um poder da fala sobre a imagem na medida em que o que é dito transcende aquilo que é visível. Dona Vitória fala de tal maneira que parece desvendar para aqueles que "ouvem o filme" um sentido maior da experiência pela qual está passando.

Deste modo constata-se que não se está diante de uma simples narração em off ou até mesmo de uma narração fundamentada, única e exclusivamente, na construção de um "monólogo interior". Integra-se a fala da Dona Vitória numa multiplicidade de sentidos e conexões dentro da qual se constitui um discurso "polifônico," isto é, um discurso capaz de produzir "uma multiplicidade de vozes da vida social, cultural e ideológica representada" (Bezerra, 2005, p.192). 


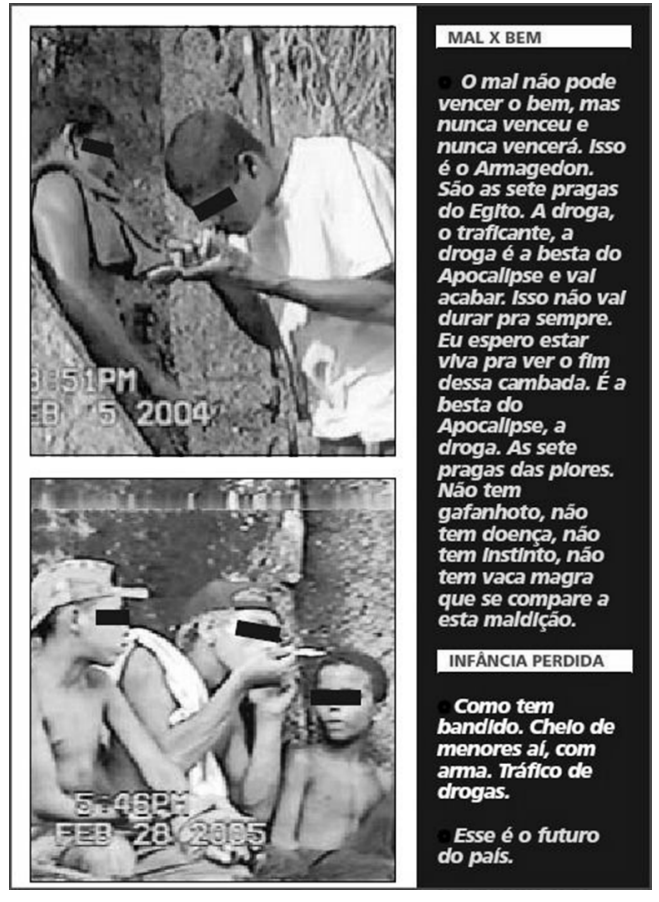

Cabe observar que, embora a matéria do romance, no qual surge a figura polifônica, e a do vídeo da Dona Vitória serem fundamentalmente diferentes, parece possível estabelecer algumas semelhanças entre elas, isto porque o discurso da aposentada traz nele algo que se aproxima de um discurso polifônico: a maneira própria dela pensar, ver, sentir, compreender a sua realidade e o mundo que a cerca.

O conceito de polifonia em Bahktin (Bakhtin, 2005, p.205-256) aparece quando ele estuda duas modalidades de romance: o monológico e o polifônico. O primeiro se constitui no monólogo que é algo "concluído e surdo a respostas do outro (...)," portanto, se constitui no discurso conclusivo. Já o segundo, o polifônico,

só pôde realizar-se na era capitalista, e justamente na Rússia, onde uma diversidade de universos e grupos sociais nitidamente individualizados e conflituosos havia rompido o equilibrio ideológico, criado as premissas objetivas dos múltiplos planos e as múltiplas vozes da existência, indicando que a essência conflituosa da vida social em formação não cabia nos limites da consciência monológica segura e calmamente contemplativa e requeria outro método de representação (Bezerra,2005, p.193).

Segundo Paulo Bezerra, para a representação literária a passagem do monologismo para a polifonia equivale à libertação do indivíduo, que no romance ocupava o lugar do escravo mudo da consciência do autor passando na polifonia a ser sujeito de sua própria consciência. "No enfoque polifônico, a autoconsciência da personagem é o traço dominante na construção da sua imagem (...)."(Bezerra, 2005, p.193).

Dona Vitória parece ser personagem de um romance polifônico ao se colocar na narrativa como participante ativa, integrante daquilo que vê através da lente da câmera. Dessa maneira, ela passa a manter relações dialógicas, isto é um tipo especial de relação entre sentidos.

Eu moro na Praça Vereador Rocha Leão (...), o meu apartamento é de fundos, bem na altura da Ladeira dos Tabajaras. Moro aqui há 35 anos (...), agora tornou-se um inferno, pois se transformou num reduto de traficantes (...). Vendem e cheiram bem em frente a minha janela que já está toda perfurada de balas. Os malditos ficam me mandando sair (...) começo a gritar, bater no parapeito com uma barra de ferro (...). Já botei vidros blindados. Tem um lado arranhado, deve ter sido um tiro. (Gusmão, 2006, p.42)

Através desse depoimento torna-se evidente que a aposentada ultrapassa a relação entre áudio e vídeo ao associar a fala a sua experiência cotidiana junto ao tráfico 
de drogas que acontece ali, diante da janela de seu apartamento. Nesses termos, Dona Vitória tem um olhar para o acontecimento que se organiza a partir de sua própria vivência junto à Ladeira dos Tabajaras e que, portanto, traz as marcas desse universo do qual ela também faz parte.

Às 17h39 da tarde do dia 29 de março de 2008, com o olho na lente da câmera, ela diz:

Tem uma vizinha que também levou um tiro na janela. Eu falei com ela: "vamos nos unir". E ela: "Deus me livre não vou fazer nada". Não faz porque ela tem parente, todos têm parentes. E quando a coisa aperta, eles vão embora, dormem fora. Mas eu não tenho ninguém aqui, estou sozinha (...).(Gusmão, 2006, p. 76).

Simultaneamente a esta fala, a imagem que está sendo captada é de um menor empunhando na mão direita uma arma. No dia seguinte, 30 de março, também à tarde, diz ela, filmando um outro menor, desta vez cheirando cocaína: "O comandante do $19^{\circ}$ Batalhão sabe disso.(...). Dei um filme para eles, mostrei os fulanos armados (...). Ele viu o filme e fez de conta que não viu. (...). Comandante de batalhão não é nenhum despreparado, ele tem experiência. Ele sabe de tudo isso". (Gusmão, 2006, p.77).

Mais uma vez torna-se evidente que a fala da aposentada traz com ela uma outra organização narrativa constituída na ruptura da conexão entre áudio e vídeo, isto é, não é relatado no áudio o que está sendo capturado naquele instante pela câmera, o que faz com que a fala da Dona Vitória seja expandida de tal maneira que é capaz de formular um tipo especial de relações entre sentidos.

Essa maneira da Dona Vitória de "contar as histórias" transforma as imagens que estão sendo mostradas; ela desvincula a imagem da voz. Deste modo, pode-se dizer que o discurso da aposentada ultrapassa a fonte que inicialmente o organiza: as imagens.

A partir desta perspectiva além de aproximar o discurso da aposentada ao sentido de polifonia trabalhado por Bakhtin - capaz de produzir uma multiplicidade de vozes - talvez se possa examiná-lo também sob a ótica da intertextualidade ${ }^{5}$, isto é, Dona Vitória na sua fala produz um texto que estabelece um cruzamento entre outros textos:

A intertextualidade pressupõe a presença de um "texto-fonte" que será como uma referência partilhada pelas instâncias de produção e de recepção. Esse cruzamento intertextual pode configurar-se em diferentes níveis: desde aquele mais pontuado na superfície do discurso até uma referência implícita a algum gênero ou produção cultural. (Dias, 2005, in CD).

No caso da Dona Vitória o texto-fonte, referência para a construção do seu relato, está nas trinta horas de gravação das ações dos traficantes na Ladeira dos Tabajaras. Dona Vitória com o olho na lente da câmera produz, a partir destas imagens, uma fala que passa, num primeiro momento, a funcionar como um efeito de presença naquele universo que está sendo filmado. Diz ela em certo momento: "olha o tamanho da sacola que deram para ele. E aquilo não dá para a noite toda não. Tem mais aqui embaixo no quiosque. Você está pensando que o sacolão aí chega?" (Gusmão, 2006, p.81).

A partir dessa fala da aposentada, é preciso fazer algumas considerações: primeiro quando diz "tem mais aqui embaixo do quiosque", produz uma fala participativa; nesse instante, ela se remete a uma outra pessoa, muito embora não esteja no local

5 A noção de intertextualidade foi introduzida na teoria literária pela especialista em semiótica Júlia Kristeva em 1966 por influência da noção de dialogicidade que Bakhtin havia desenvolvido no seu livro A Estética da palavra. 
onde se passa a ação e sim na janela de seu apartamento, próximo ao local. Em segundo lugar, Dona Vitória deixa transparecer que, além de ser a emissora da fala, é também sua receptora ao tecer considerações sobre aquilo que está filmando ao dizer: "E aquilo não dá para a noite toda não". Ao mesmo tempo, ela justapõe a emissão do relato ao outro ao concluir: "você está pensando que o sacolão aí chega?" Em outras palavras, ela reage ao que vê e dá a sua opinião como se estivesse podendo falar com um dos personagens que ela filma.

Alguns aspectos desse jogo de emissão/ recepção realizado através do relato da aposentada merecem ser enfatizados também a partir de uma perspectiva visual: um deles pode associar ao zoom, movimento frequentemente usado nas imagens capturadas por "Dona Vitória". O zoom é um efeito conhecido e bastante comum na produção de imagens, constituise, basicamente, na graduação das lentes da câmera capaz de provocar movimentos de aproximação e afastamento daquilo que está sendo filmado; o Zoom é capaz, portanto, de eliminar distâncias. A câmera usada pela aposentada é uma - VHS - Very High frequency - de fácil manipulação e de comando automático, logo o efeito Zoom é facilmente disparado por ela durante a filmagem.

Esse efeito parece explicar a fala de Dona Vitória: "Tem mais aqui embaixo do quiosque". A aproximação da imagem provoca naquele que está com o olho na lente, uma sensação momentânea de estar no local da cena, ou melhor, o "quiosque" ao qual ela se refere se torna, no instante da visão em zoom, tão próximo que é, de certo modo, transportado para dentro do seu próprio apartamento. Como ela mesma diz: "aqui embaixo".
Ao destacar o efeito do Zoom nas imagens da Dona Vitória, quer chamar a atenção para a produção do que se nomeou há pouco de fala participativa, uma fala que pode também ser produzida por uma outra consciência, esta capaz de emergir mediante o efeito de uma imagem.

Falou-se anteriormente que a intertextualidade se configura no cruzamento de textos, num entrelaçamento intertextual, como se está falando das imagens produzidas por Dona Vitória. É importante frisar que isso não ocorre somente com textos: "Não só o texto literário é envolvido pela noção de intertexto. Para Barthes não se pode viver fora do texto infinito, quer seja ele o jornal, a tela da TV, ou acrescentaríamos, ainda, o som de cada dia" (Dias, 2009)

Há ainda uma outra questão: afirmou-se há pouco que Dona Vitória justapõe sua fala a um outro quando diz: "Você está pensando que o sacolão aí chega?" Neste instante, ela compartilha, de forma literal, com um outro, a realidade que se passa diante de seus olhos. Esta fala remete ao estudo desenvolvido por Bakhtin sobre a obra de Dostoievski onde ele afirma que:

a autoconsciência do herói em Dostoievski é totalmente dialogada: em todos os seus momentos está voltada para fora, dirigi-se intensamente a si, a um outro, a um terceiro. Fora desse apelo vivo para si mesma e para outros ela não existe nem para si mesma.(...). Representar o homem interior como o entendia Dostoiévski só é possível representando a comunicação dele com um outro. Somente na comunicação, na interação do homem com o homem revela-se o "homem no homem" para outros ou para si mesmo. (Bakhtin,2004, p.256)

Sendo assim, toda e qualquer fala é marcada pela referência do outro, a fala é, pois, constituída nesta conjunção entre o eu e o eu do outro. "Como é que vou viver assim? 
Me tira daqui, meu Deus, me tira! (chora). Por causa das autoridades, estou vivendo uma situação dessas. (chora de soluçar). Oh, meu Deus, não é possível." (Gusmão, 2006, p.57)

Para Bakhtin, o homem, ao falar, não apenas se revela exteriormente como também torna-se, aquilo que é não só para os outros, mas para si mesmo. "Ser significa comunicarse pelo diálogo. Quando termina o diálogo, tudo termina." (Bakhtin, 2005, p.257). Bakhtin observa através dos personagens de Dostoievski que a figura do outro se desintegra em dois campos: em um "estou eu", no outro "estão eles", no caso de Dona Vitória: "E aquilo não dá para a noite toda não. (...). Você está pensando que o sacolão aí chega?". Na primeira sentença, a conexão se configura no "estou eu" enquanto que na segunda se propaga o "estão eles".

Ainda há outra questão: no diálogo proferido pela aposentada parece existir uma particularidade na figura deste outro, pois dele emerge uma identidade. Ao deslizar a lente da câmera sobre as cenas que se desenvolvem na Ladeira dos Tabajaras, Dona Vitória passa a constituir um material de denúncia que serviria como prova da insegurança vivida por ela, cotidianamente, para a Defensoria Pública. Só mais tarde estas imagens convertem-se em material para a imprensa.

\section{O jornalismo e a fala monológica}

Ao contrário da polifonia que produz uma multiplicidade de vozes perturbadoras, o discurso da imprensa parece integrar-se, de certo modo, ao processo do discurso monológico.

O modelo monológico não admite a existência da consciência responsiva e isônoma do outro; para ele não existe o "eu" isônomo do outro, o "tu". O outro nunca é outra consciência, é mero objeto (...). O monólogo é algo concluído e surdo à resposta do outro (...).Descarta o outro como entidade viva, falante e veiculadora das múltiplas facetas da realidade social (...). (BEZERRA, in: BRAIT, (Org), op. cit., p.192)

A linguagem jornalística, por almejar "objetividade", se contrapõe a uma linguagem fundamentada na experiência que está ligada ao mundo subjetivo. Nesse caso, "o outro nunca é outra consciência, é mero objeto". Muito embora a imprensa dedique alguns de seus espaços (seção de cartas, Eu, Repórter) ao leitor/espectador, não quer dizer que não exista um aprisionamento empresarial e ideológico naquilo que chega até ela. $\mathrm{O}$ que vem de fora da sua própria produção é absorvido e incorporado ao seu discurso de maneira que possa reproduzi-lo.

As reportagens produzidas nos telejornais, em especial, parecem trazer uma espécie de discurso monológico que se configura nos textos offs. O off na produção das reportagens de televisão é parte fundamental da narrativa, é ele que dá coerência ao que está sendo narrado que apreende/prende de maneira ordenada o acontecimento.

Desse modo, as reportagens exibidas nos telejornais chegam até o espectador entrelaçadas pelas imagens e pelo off, esse último legitima de maneira definitiva aquilo que é visível. Isso significa que o que está visível na tela da televisão está vinculado à objetividade do que é dito. Nesse caso, as falas dos entrevistados, partes integrantes das reportagens, são acomodadas nos intervalos dos offs ${ }^{6}$, linha mestra da narrativa. O off é, portanto, uma estrutura narrativa que busca integrar a imagem a uma verdade que passa

6 Para um melhor esclarecimento importante lembrar que em uma única reportagem podem-se ter diversos offs. 
distante da experiência daquele que narra.

No caso da voz off da Dona Vitória ocorre exatamente o contrário. A aposentada constrói uma narrativa subjetiva e autônoma das imagens. Essa ruptura na relação entre o que é visto e o que é dito dá ao material fílmico uma dimensão que foge ao caráter narrativo clássico de construção do off, e nesse caso transparece algo que não está na imagem mas no áudio.

A expressão sonora é, pois, aquela que tem o som (e o próprio silêncio) como suporte, como substância ou como principal material. A expressão sonora supõe uma determinada percepção, (...). Poderíamos, por exemplo, observar que a percepção visual tem um aspecto fortemente analítico e que a percepção auditiva é essencialmente sintética. Por síntese entenda-se esta capacidade de unir ou reunir, por análise entenda-se a capacidade de distinguir de separar. (SÁ, Leonardo O Sentido do Som. In: NOVAES, op. cit., p.124)

A distinção que o músico Leonardo Sá faz entre o visível e o sonoro associando o que é dado aos olhos como algo capaz de distinguir e separar e aquilo que é dado aos ouvidos, ao contrário, é para unir e reunir leva a outras reflexões sobre o vídeo realizado por Dona Vitória.

Muito embora exista ruptura entre áudio e vídeo na filmagem, observa-se que a voz da aposentada é simultânea, sincrônica, às imagens das ações do tráfico de drogas que ocorre na Ladeira dos Tabajaras. Nesse caso há entre áudio e imagem um outro tipo de união que vai se configurar, não em legitimar aquilo que está visível (como faz o jornalismo), mas em fazer uma conexão temporal/experiencial no interior deste fluxo onde a união entre imagem e áudio adquire uma temporalidade de tempo presente só possível, conforme diz Norbert Elias, (ELIAS, Norbert. Sobre o Tempo. Rio de Janeiro: Jorge
Zahar, 1998, p.63) "quando o indívíduo se encontra em determinado instante no interior de um fluxo contínuo no qual esteja vivendo."

$\mathrm{Na}$ literatura, este instante interior, no qual se encontra a personagem, remete a um tempo interior que explora as "virtualidades da memória e da retrospecção e devassando o enredado mundo interior das personagens" (SILVA, op. cit., p.295.). A fala da Dona Vitória se integraria nesta formulação já que ela se coloca, na narrativa, como participante, integrante daquilo que vê através da lente da câmera estabelecendo, desta forma, "relações dialógicas, isto é, aquele "tipo especial de relações entre sentidos" (BEZERRA, in BRAIT, (Org), op. cit., p. 197).

\section{A propagação do monólogo: a emergência de um novo acordo midiático}

A obra testemunhal da aposentada vem a público no dia 24 de agosto de 2005, no jornal Extra, a história ganha um caderno especial, intitulado "Janela Indiscreta"

ELA DEU UM BASTA
“Olha aí o futuro do Brasil. Não é possível, minha
gente,
essas crianças cheirando pó e ninguém fazer nada"
Dona Vitória
FÁBIO GUSMÃO
fa b i o g @ ex tra . i f. br
Uma câmera na mão e muita indignação no coração.
Foi assim que Dona Vitória (nome fictício), uma
aposentada de 80 anos de Copacabana, resolveu dar
um basta na rotina de violência com que grande parte
da população do Rio convive como se fosse normal.
Mas para Dona Vitória não era normal ter como
despertador os tiros vindos da Ladeira dos Tabajaras,
em Copacabana (...)Jornal Extra $24 / 08 / 2005$ - p.17

Ao ser inserido e divulgado na mídia o material - imagem/áudio - sofre um deslocamento, isto é, aquilo que antes serviria apenas como material de denúncia é 
transformado em matéria jornalística, num primeiro momento, para os leitores do jornal e depois para os espectadores da televisão. É preciso ressaltar que este tipo de material, especificamente as imagens, produzidas por cinegrafistas amadores, como no caso da Dona Vitória, ou pelas câmeras de vigilância ao ser exibido na TV traz com ele uma outra visibilidade porque são imagens que não obedecem ao "padrão de qualidade", até pouco tempo, tão exigido, em especial, por uma das maiores emissoras de televisão do país. Este padrão de imagem estava relacionado ao grau de realidade/veracidade do acontecimento provocado no espectador.

Pode-se dizer que a televisão mantinha com seus espectadores um tipo de combinação na qual a verdade/ realidade dos acontecimentos estava inscrito na exibição de uma imagem de boa qualidade. Na atualidade pode-se afirmar que este tipo de combinação foi rompido dando lugar a um outro acordo estético este estabelecido a partir do uso, por grande parte da população, dos novos dispositivos de visibilidade como telefones celulares, câmeras fotográficas e microfilmadoras digitais, etc., tornando estes indivíduos produtores de imagens que passaram a ser inseridas, quase que diariamente, nas produções dos telejornais e que apesar de serem imagens de qualidade duvidosa, por vezes em preto e branco e com nitidez e áudio prejudicados, são capazes de estabelecer, no espectador, uma sensação de realidade/verdade tal qual as imagens convencionais, ou melhor, de forma muito mais convincente dos que as imagens de boa qualidade.
Desse modo, "certas tecnologias e estilos nos estimulam a acreditar numa correspondência estreita, senão exata, entre imagem e realidade (...)" (NICHOLS, Bill. 2005, p.19). São imagens que "parecem garantir a autenticidade do que vemos" (Ibid.). Thomas Levin fala que os indícios de verdade nas imagens foram deslocados para as imagens de vigilância e/ou para aquelas capturadas de imprevisto, fora do controle e nesse caso passam a expressar uma verdade que aquelas produzidas pela televisão não conseguem mais. Levin identifica nas imagens de vigilância o regime visual do real. Diz ele: "quando vemos aquilo que consideramos ser uma imagem de vigilância, geralmente não perguntamos se é "real" (simplesmente assumimos como tal)" (LEVIN, Thomas Y. 2009, p.183)

Jaques Aumont, ao falar do efeito de realidade que une, no cinema, a imagem ao espectador, diz que : "o efeito de realidade será mais ou menos completo, mais ou menos garantido, conforme a imagem respeite convenções de natureza plenamente históricas (...)." Nesse caso, um bom exemplo seria o filme A Bruxa de Blair de Eduardo Sanchez e Daniel Myrick de 1999. Para dar credibilidade à narrativa ficcional (o filme conta com "imagens originais" encontradas numa fita de vídeo, a história de três cineastas que desaparecem tragicamente), seus realizadores trabalham com imagens capturadas com a câmera na mão, baixa fidelidade de som e luz que trazem com elas uma forte dose de realismo.

No caso das imagens de vigilância e aquelas produzidas por Dona Vitória trazem consigo uma forte dimensão documental. No entanto é preciso observar algumas diferenças entre as imagens de vigilância capturadas pelas câmeras automáticas e as filmagens de Dona Vitória que expressam 
através do áudio uma narrativa pessoal, subjetiva, um ponto de vista sobre o mundo. O relato da aposentada, ao contrário do relato jornalístico que constrói uma narrativa supostamente objetiva do acontecimento faz com que o espectador acompanhe a trama além das imagens que estão sendo exibidas. Com isto se está querendo dizer que o espectador é capaz de ver o que está ausente, como a dor e o desespero da Dona Vitória.

"O que chama a atenção no aparecimento desta outra estética é o fato de que estas novas imagens passaram a ganhar, junto ao espectador, uma forte dimensão que existe um catálogo de regras representativas que permitem evocar, ao imitá-la, a percepção natural (...)." (AUMONT, Jacques,1993, p111). Trata-se de imagens, na sua maioria, capturadas ao acaso, como, por exemplo, as do desmoronamento da estrutura de escavações de uma galeria da linha 4 do metrô na cidade de São Paulo, em janeiro de 2007, quando um indivíduo de posse de um telefone celular filmou o acidente no instante em que a obra começava a desabar. As imagens foram exibidas, em rede nacional, num dos telejornais de maior audiência do país.

Muito embora as imagens captadas por Dona Vitória, na Ladeira dos Tabajaras, não tenham sido ao acaso, como no exemplo que se acabou de citar, mas, ao contrário, eram ações que já preexistiam à filmagem e que é bom ressaltar, não traziam com elas, ao serem exibidas na televisão, nenhum ineditismo, pois vez por outra os espectadores assistem na tela da TV a menores traficando drogas e, até mesmo, fazendo uso delas nos espaços públicos da cidade, no entanto elas engendram um outro ineditismo - este não se configura na visibilidade das ações, mas naquilo que é dito por Dona Vitória nas mais de trinta horas de gravação levando o espectador da TV a vivenciar uma outra experiência diante da tela, desta vez não mais fundamentada nas imagens e sim na narrativa improvisada da aposentada.

A condição para esta experiência está na disjunção que existe entre a imagem e o áudio do material, isto é, a narrativa não está necessariamente atrelada à evidência da imagem, embora ela só tenha se revelado a partir daquilo que era filmado por Dona Vitória, no entanto é a fala que é a força de relação daquelas imagens. Diferentemente das imagens de vigilância capturadas pelas câmeras automáticas ou mesmo por agentes policiais, as imagens de Dona Vitória expressam claramente uma narrativa pessoal, subjetiva, um ponto de vista sobre o mundo. Essa expressividade contida no vídeo redimensiona, de certa forma também, o lugar do espectador que, ao ouvir a confissão de solidão, medo e abandono vividos pela aposentada é instigado a uma "sensação de intimidade" em função do efeito provocado por este tipo de fala compartilhada, estruturada numa relação tripolar: eu falo de mim para você a partir deles. ${ }^{7}$ O teórico americano Bill Nichols, ao falar da relação entre as formas da retórica e as vozes da enunciação de um documentário, afirma que:
falar na primeira pessoa aproxima o documentário do diário, do ensaio e de aspectos do filme e do vídeo experimental ou de vanguarda. A ênfase pode se transferir da tentativa de persuadir o público de um determinado ponto de vista ou enfoque sobre um problema, para a representação de uma opinião pessoal, claramente subjetiva. (...). $\mathrm{O}$ que ganha expressão é o ponto de vista pessoal e a visão singular do cineasta. (NICHOLS, 2005, p.41)

7 Um modo de pensar a interação entre cineasta, tema e espectador consiste na relação clássica estruturada em: Eu falo deles para você. NICHOLS, op. cit., p.40 
De modo algum se está aqui incluindo Dona Vitória no rol das mais recentes documentaristas brasileiras. Ela não quis, de forma consciente, dirigir um documentário nem realizar uma obra; trata-se de um diário filmado e não de um filme-diário, isso faz toda a diferença. Diários filmados são realizados atualmente por indivíduos comuns e em grande quantidade através do fácil acesso aos dispositivos visuais disponíveis no mercado, mas transformar esse material em filme não é um procedimento tão simples. O caso celebre na história do cinema é a obra de Jonas Mekas, ${ }^{8}$ que filmou fragmentos de sua vida e a dos amigos desde o final dos anos 50, mas o material só se transformou em filme quando ele montou imagens e sons no final dos anos 60 . É quando, então, o material transformou-se em um filme ${ }^{9}$. O material de Dona Vitória manteve-se no primeiro estágio.

No entanto, inegavelmente, as imagens "produzidas" por ela abrem, como já se viu, um horizonte de possibilidades no campo da relação imagem/narrativa - uma delas estaria na aproximação do vídeo, por ser narrado em primeira pessoa, de um documentário/ diário já que ele expressa, como afirma Bill Nichols, uma opinião pessoal e subjetiva da aposentada sobre os acontecimentos na Ladeira dos Tabajaras. É preciso observar que a imagem, não só a narrativa na primeira

8 Jonas Mekas nasceu na Lituânia em 1922 e foi radicado na cidade de Nova York. Mekas registrou momentos da sua vida que resultaram em nove "filmes diários" .Entre eles: Welden (1968), Reminiscenses of a Journey to Lithuania (1972) e Loste, Lost, Lost...(1976). 9 Transformação do diário filmado (valor de uso) em filme-diário (valor de troca). Diário filmado: privilegia o autor, o procedimento e o instante de composição, assim como a reunião artificial de fragmentos heterogêneos. Filme-diário se inscreve na economia do filme, que privilegia o objeto constituído como um todo, o momento da projeção, o público de espectadores. In: JAMES,David E.: "Journal Filmé/Film journal: Pratique et produit dans Walden de Jonas Mekas", Le livre de Walden, Editions Paris Expérimental, Ligth Cone Vidéo, 1997. pessoa, estimula este tipo de leitura do material, ao levar também até o espectador - configuradas ao lado esquerdo da tela - informações, como as tradicionalmente inseridas nos diários: dia, mês, ano e hora em que transcorreram aquelas ações, "vividas" pela aposentada: 4:34 PM. MAR:27, 2004:

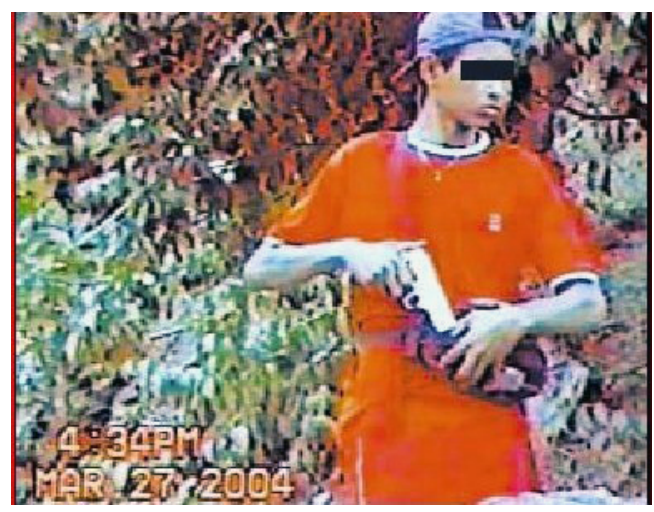

Não sei mais o que fazer. Completamente atordoada. Por culpa de quem? Por culpa do Estado(...). Estou fazendo papel de maluca aqui. (GUSMÃO, op. cit. p.85)

Além do fato da imagem trazer as características fundamentais de um diário, como se acabou de constatar, ela traz também para o espectador, ao cronometrar sequencialmente o instante da captação das cenas, isto é, 04h34min PM, 04h35min PM etc., um outro grau de credibilidade diferente daquele provocado pelas imagens tradicionalmente exibidas nas reportagens dos telejornais, pois, ao exibir sequencialmente durante a gravação a hora exata em que as ações se desenvolveram, torna-se evidente, para o espectador, a ausência de edição dessas imagens.

\section{Bibliografia}

AUMONT, Jacques A Imagem. Campinas: Papirus, 1993.

BAKHTIN, Mikhail Problemas da Poética de Dostoievski. Rio de Janeiro: Forense Universitária, 2005. 
BEZERRA, Paulo Polifonia. In: BRAIT, Beth (Org).

Conceitos Chave. São Paulo: Contexto, 2005.

BRUNO, Fernanda e LINS. Consuelo, Estéticas da Vigilância. Revista GLOBAL - Brasil, Rio de Janeiro: Rede Universidade Nômade, n. 7, dez/jan/fev, p. 38-39, 2007

DIAS, Maria Helena Pereira. Hipertexto o Labirinto Eletrônico, uma experiência hipertextual. Disponível em: < http://www.unicamp.br/ hans/ mh/intersec.html > . Acesso em: 4 fev. 2009.

DUJARDINB apud SILVA, Vitor Manoel Aguiar Teoria da Literatura. São Paulo: Almedina, 2004.

FOUCAULT, M. Vigiar e Punir, Petrópolis: Vozes, 1977.

GUSMÃO, Fábio Dona Vitória da Paz. São Paulo: Planeta do Brasil, 2006.

LEVIN, Thomas Y. Retórica do índex temporal: narração vigilante e o cinema de "tempo real". In : MACIEL,K. (org) Transcinemas, Rio de Janeiro: Contracapa, 2009.

LYSARDO-DIAS, Dylia O Discurso Publicitário: dialogismo e heterogeneidade. Intercom, set. 2005. CD-ROM

MACHADO,Arlindo Máquina e Imaginário, S.Paulo: Editora USP, 1993.

NICHOLS, Bill. Introdução ao documentário. São Paulo: Papirus, 2005.

VIRILIO,P. A Arte do Motor. S.Paulo: Estação Liberdade, 1996. 
